Au Massachusetts Institute of Technology, on a rassemblé plus de 150000 observations optiques du Soleil, de la Lune et des planètes, pour la période 1750 à 1968 et un certain nombre de solutions du mouvement des planètes ont été obtenues par intégration numérique du système de masses planétaires (4).

Par ailleurs, l'U.S. Naval Observatory a procédé à l'analyse de la précision des éphémérides existantes, notamment des grosses planètes (5) tandis que des études étaient faites à l'Institut d'Astronomie Théorique de Léningrad sur le calcul des Éphémérides (6) et (7).

\title{
BIBLIOGRAPHIE
}

1. O'Handley, D. A. and Lieske, J. H. $\quad$ 1971, Bull. Amer. Astron. Soc., 3, 467.

2. Lieske, J. H., Melbourne, W. G., O'Handley, D. A., Holdridge, D. B., Johnson, D. E. and Sinclair, W. S. 1971, Celestial Mechanics, 4, 233.

3. Oesterwinter, C. and Cohen, C. J. 1972, Celestial Mechanics, 5, 317.

4. Ash, M. E., Shapiro, I. I. and Smith, W. B. 1971, Science, 174, 551.

5. Duncombe, R. L., Klepczynski, W. J. and Seidelmann, P. K. 1972, Astronautics and Aeronautics, 10, No. 8 .

6. Izvekov, V. A. 1972 , Bull. Inst. Theor. Astr., 13, No. 4.

7. Gromova, O. M. and Malkova, A. G. $\quad$ 1972, Bull. Inst. Theor. Astr., 13, No. 7.

\section{ÉPHÉMÉRIDES DE LA LUNE ET TE2}

Le lancement de nombreuses sondes lunaires habitées ou non, et le fait que l'on mesure maintenant de façon systématique la distance Terre-Lune par laser ont rendu plus nécessaire que jamais la construction d'éphémérides précises de la Lune. Nous tirons du rapport de J. D. Mulholland la description des efforts faits dans ce domaine:

"During the triennum, considerable progress has been made towards the construction of a very high-precision numerical ephemeris of the Moon. A preliminary step in this effort was the use of a combination of literal and numerical integration techniques to produce a lunar ephemeris free of the gravitational defect inherent in the Brown lunar theory, due to a series truncation in the planetary terms (1). This ephemeris, which was developed by the writer while at the Jet Propulsion Laboratory, was intended to serve as the primary prediction ephemeris for the Apollo Lunar Laser ranging Experiment, a role that it is still fulfilling. It is based on the same observational material as is the Brown Lunar theory.

Another ephemeris (JPL designation LE 17) was obtained through a completely gravitational numerical integration of the Moon's orbit fitted to U.S. Naval Observatory transit circle observations over the interval $1950-1968$ by J. D. Mulholland. It differs from the first ephemeris described above on the scale of two to three hundred meters. In comparison with observations, both transit circle and lunar ranges, it proved not to be better or worse".

Les observations systématiques de distance laser Terre-Lune ont d'ores et déjà permis d'améliorer les éphémérides de la Lune. W. G. Melbourne écrit à ce sujet:

"The ability to analyse lunar laser range data has been developed by P. Bender, J. D. Mulholland and J. G. Williams. Current laser ranging observations from McDonald observatory are considered to be accurate to better than $15 \mathrm{~cm}$. Solutions can be made for the lunar elements, the observatory and reflector coordinates and physical libration parameters. These solutions show significant corrections to the lunar eccentricity, mean anomaly and longitude of perigee. New numerical integrations with the improved elements" (University of Texas Integrated Ephemeris No. 1 and JPL ephemeris LE 18) "confirm the significant decrease in the range residuals. However, the residuals are still considerably larger than the inherent accuracy of observations. The existing physical libration model appears to be the main limitation to the present analysis of laser data. The libration model is being improved at JPL".

Les efforts parallèles faits pour améliorer la théorie analytique de la Lune ou pour rassembler des 
observations précises (par laser ou par enregistrement d'occultations) sont décrits dans les rapports des Commissions 7 et 17.

Par ailleurs, la réduction des observations de la Lune et leur comparaison avec les éphémérides $j=2$, ont conduit à des résultats nouveaux concernant le temps des Ephémérides TE2.

C'est ainsi que G. A. Wilkins (H.M. Nautical Almanac Office) écrit:

"The analysis of some 50000 total-occultation observations from 1943 to 1972 is almost complete, and the results are being prepared for publication; the analysis for 1955 to 1972 confirms that the length of the ET2-second is increasing with respect to the SI-second, and suggests that the tidal term in the expression for the Moon's mean longitude should be about $-20^{\prime \prime} T^{2}$, and not -11 " $22 T^{2}$ as currently adopted.

N.B. The digitized version of C. B. Watt's charts of the marginal zone of the Moon is in regular use for the reductions and copies may be made available in appropriate circumstances".

On notera à ce sujet, les travaux effectués parallèlement à l'U.S. Naval Observatory et qui conduisent à des conclusions analogues en ce qui concerne l'accélération séculaire de la Lune (coefficient du terme en $T^{2}$ égal à $26^{\prime \prime} \pm 8^{\prime \prime}$ ) et d'autres éléments ( 2 et 3 ). Des études y ont aussi été effectuées pour utiliser les observations d'instants d'éclipses du Soleil pour comparer les systèmes de référence de Newcomb et des Improved Lunar Ephemeris (4).

Par ailleurs, l'intégration numérique du mouvement de la Lune et des planètes, effectuée au Naval Weapons Laboratory (5) a permis d'évaluer à $-19^{\prime \prime} \pm 4^{\prime \prime}$, le terme en $T^{2}$ dans la longitude de la Lune, en bon accord avec les autres évaluations. Notons enfin qu'en analysant les éclipses de l'antiquité, R. R. Newton avait obtenu des valeurs moyennes de l'ordre de $-21^{\prime \prime}$ pour les trois derniers millénaires (6).

\section{BIBLIOGR A P HIE}

1. Garthwaite, K., Holdridge, D. B. and Mulholland, J. D. $\quad 1970$, Astron. J., 75, 1133.

2. Van Flandern, T. C. 1970 et 1971 , Astron. J., 75, 657 et 76, 81.

3. Van Flandern, T. C. and Martin, C. F. 1970, Science, 168, 246.

4. Duncombe, R. L., Haupt, R. F. and Duncombe, J. S. 1971, Solar Physics, 21, 260.

5. Oesterwinter, C. and Cohen, C. J. 1972, Celestial Mechanics, 5, 317.

6. Newton, R. R. 1969 , Science, 166, 825 .

\section{PUBLICATION DES ÉPHÉMÉRIDES NATIONALES ET INTERNATIONALES}

Les divers services nationaux des éphémérides ont continué la publication de leurs ouvrages annuels comme les années précédentes, désormais en conformité avec le systéme UAI de constantes (voir plus haut).

Les trois principales publications de l'U.S. Navel Observatory Nautical Almanac Office et du H.M. Nautical Almanac Office de l'Observatoire Royal de Greenwich continuent à être publiées sous une forme unifiée: The American Ephemeris and Nautical Almanac ou The Astronomical Ephemeris pour les astronomes, The Nautical Almanac pour les navigateurs et The Air Almanac pour la navigation aérienne. Le nouveau Superintendant du H.M. Nautical Almanac Office, G. A. Wilkins, écrit:

"...these almanacs... are printed separately from identical reproducible material; this material can be made available by Her Majesty's Stationery Office, at a small charge, to the official Almanacproducing agency in any country that desires to publish similar ephemerides in this form"...

"The fundamental ephemerides of the Sun, Moon and planets to be published in Astronomical Ephemeris 1974-76 have been distributed on a limited basis to ensure that these data are available for the preparation of navigational and other almanacs in other countries".

Effectivement, ces tableaux relatifs au Soleil, à la Lune et aux planètes, qu'ils soient utilisés tels quels ou qu'ils soient recopiés, servent à l'élaboration de nombreuses Ephémérides astronomiques des autres pays: The Japanese Ephemeris (Hydrographic Department, Maritime Safety Agency, Tokyo), The Indian Ephemeris and Nautical Almanac (Nautical Almanac Unit, India Meteorological 
Department, Calcutta), Astronomicheskij Ezhegodnik S.S.S.R. (Institut d'Astronomie Théorique, Leningrad), Éphemerides Astronomicos (Instituto y Observatorio de Marina, San Fernando) la Connaissance des Temps, (Bureau des Longitudes, Paris), utilise ces données seulement pour les tableaux relatifs à la Lune et le temps sidéral.

Les phénomènes et les configurations des satellites de Jupiter calculés et dessinés par le Bureau des Longitudes et issus des Ephémérides publiées par la Connaissance des Temps sont également publiés sans changement par la plupart des autres Ephémérides nationales.

Les services nationaux ont rendu compte à la Commission de la poursuite de la publication de leurs autres ouvrages destinés aux navigateurs, aux aviateurs ou aux géodésiens. Nous donnons ci-après les changements apportés à ces publications ou les travaux nouveaux ou spécialisés récemment effectués dans le domaine des calculs d'éphémérides par ces services.

\section{Astronomisches Rechen-Institut, Heidelberg, F.R.G.}

Prospects and plans for an improvement of the FK4 and its extension to fainter stars are being developed. The documentation of observational data on punched cards has been continued under the supervision of Lederle; The U.S. Naval Observatory and the Centre de Données Stellaires at Strasbourg have contributed efficiently to this task by providing star catalogues on punched cards. A computer program for the identification of stars in different catalogues has been developed and applied at Heidelberg. The program for deriving systematic differences in star positions between catalogues has been improved. Gliese and Strobel have started the examination of new catalogues as well as of unpublished data to be used for the compilation of the FK5.

\section{Bureau des Longitudes, Paris, France}

Les Éphémérides Aéronautiques sont désormais publićes par 'SONOVISION', 104 rue de Castagnary, 75015 Paris. Par ailleurs, le Bureau des Longitudes a renoncé à l'amélioration de la présentation des éphémérides de satellites galiléens de Jupiter annoncée en 1970 (Transactions UAI, Vol. XIVA, p. 5) qui aurait entraîné une trop forte augmentation du nombre de pages. En revanche, il est possible de fournir sous forme de listages ou de cartes, les coordonnées des satellites à un instant quelconque.

\section{Ephemeris Department of the Institute for Theoretical Astronomy, Leningrad, U.S.S.R.}

The regular publication of the ephemeris of the lunar crater Mösting A has been continued in the volumes of the Astronomical Yearbook of the U.S.S.R. To the volumes of this publication for 1975 and 1976, appendices were published containing the ephemerides of the four ancient (Galilean) satellites of Jupiter for 1973 and 1974, as well as for 1975 and 1976, computed in, and received from the Bureau des Longitudes, France.

\section{H.M. Nautical Almanac Office, Royal Greenwich Observatory, Herstmonceux, U.K.}

As an experiment, special tabulations of the times of rising and setting of the Sun and Moon, and also twilight times and other general data that are relevant to the planning and making of observations, were supplied to a small number of observatories for 1972. These were well received and it is intended to continue and, hopefully, to extend the provision of this service.

The new series of Sight Reduction Tables for Marine Navigation in six volumes, and a new edition for epoch 1975.0 of Volume 1 of Sight Reduction Tables for Air Navigation, have been published. These tables were prepared jointly with the Nautical Almanac Office, U.S. Naval Observatory and the U.S. Naval Oceanographic Office.

Occultation programme. The regular distribution of the predictions of occultations of stars and radio sources by the Moon has been continued and extended in some respects. Maps of the predicted 
tracks of grazing occultations are now prepared for several journals and more detailed predictions are supplied to observing groups. Occultations of some additional minor planets are now also prepared, with a view to the possible determination of their diameters from photoelectric observations.

In addition to the work on the occultations of radio sources, the Office now provides predictions for the occultations of X-ray sources and other objects as seen from rockets and satellites.

The predictions of occultations of stars by planets are becoming increasingly important now that photoelectric equipment is more widely available and transportable. The search for the predictions of occultations by minor planets is being extended to cover all minor planets whose diameters are believed to exceed $50 \mathrm{~km}$, and for which accurate ephemerides are available; the Office is grateful for the assistance provided by the Institut of Theoretical Astronomy in Leningrad for preparing special ephemerides for use in this programme. Searches for possible occultations of stars by natural satellites are also now carried out on a limited scale.

\section{Hydrographic Department, Maritime Safety Agency, Tokyo, Japan}

At its three branch observatories in the country, the Department has obtained about 600 data of occultation observations, including about 100 photoelectric data, annually. The provisional result of reduction analysis has been widely circulated annualy. The value of $\Delta T$ for use in prediction of eclipses and compilation of almanacs and the national calendar, latter of which is published by the Tokyo Astronomical Observatory, has been settled by arrangement with Tokyo Astronomical Observatory from the above result of occultation observations, taking into account the tendency of AT-UT.

Prediction of occultations of bright minor planets $(m>10)$ by the Moon has been made continuously and widely circulated.

\section{Instituto y Observatorio de Marina, San Fernando, Spain}

The work in this Ephemeris has been to continue the publications as usually. In the computation of the lunar ephemeris for the Almanaque Nautico, we have adopted the Tchebitchev's coefficients.

Nautical Almanac Office, U.S. Naval Observatory, Washington, U.S.A. (see also H.M. Nautical Almanac Office)

Computer-controlled photocomposition methods are now being utilized for the production of The Air Almanac commencing with the 1969 edition, The Nautical Almanac commencing with the 1975 edition, Astronomical Phenomena, Publications of the U.S. Naval Observatory, and over half of The American Ephemeris and Nautical Almanac.

The navigational almanacs have continued to be published with minor changes. Information concerning the introduction of time signal transmissions on the new Coordinated Universal Time (UTC) system was provided in the navigational almanacs, Notices to Mariners, and other publications.

The preparation of advanced predictions of solar eclipses (1981-1985) in accordance with the recommendation of the International Astronomical Union has been continued. Circumstances of solar eclipses with argument in UT have also been prepared (U.S. Naval Obs. Circ. No. 126, 129, 135).

A special ephemeris for the radio longitude of the central meridian of Jupiter system III has been continued for the years 1972 to 1975 (U.S. Naval Obs. Circ. No. 137).

Additional astronomical information has been prepared and published in U.S. Naval Observatory Circulars to meet public demand (perigee and apogee of the Moon, 1959-1999 (No. 130), Geocentric Solar Data (No. 138), Astrometric Ephemeris of Pluto 1970-1990 (No. 139) and Rectangular Coordinates of the Moon 1971-1980. 


\section{Nautical Almanac Unit, Regional Meteorological Centre, Indian Meteorological Department, Calcutta, India}

Calculations of geocentric longitudes and latitudes of planets, at the ending moments of tithis, nakshatras and yogas have been made on computer commencing from the issue for 1972 of the Indian Ephemeris and Nautical Almanac.

\section{Autres rapports}

J. Arias de Greiff a adressé un compte-rendu de publication de l'Annuario del Observatorio Astronomico de Bogota.

\section{Président de la Commission}

\section{ANNEXE 1: RAPPORT DU GROUPE DE TRAVAIL SUR LES CONSTANTES DE LA PRÉCESSION}

There has been an exchange of opinions between the members of the Working Group by correspondence, and, in addition, some results have become available concerning the strength of the evidence for new values. The prevailing opinion is that:

(1) the problems should be discussed in the Joint Discussion No. 1;

(2) no final decisions should be made at the IAU General Assembly in Sidney;

(3) decicions on precession should be made simultaneously with decisions on planetary masses.

On this basis, I suggest that the Working Group continues its activities beyond the XV General Assembly.

\section{W. FRICKE \\ Chairman of the Working Group}

\section{ANNEXE 2: RAPPORT DU GROUPE DE TRAVAIL SUR LES UNITÉS ET LES ÉCHELLES DE TEMPS}

The Group consists of Chebotarev, Clemence, Cook, Guinot, Kovalevsky, Morrison (Secretary), Shapiro, Van Flandern and Wilkins (Chairman). In addition, D. H. Sadler and Duncombe have made many helpful comments and suggestions on the matters under consideration. The Group was asked to consider: the effects of changes in the system of precessional constants on the definition and determination of astronomical time-scales and distances; the most appropriate form for the definition of the astronomical unit of distance; the relationship between ephemeris time and atomic time; and the possible need for new definitions of the unit and epoch of ephemeris time. The Group has worked largely by correspondence, although naturally there have been oral discussions whenever any members of the Group have met.

There is still a wide divergence of opinion amongst the members of the Group on the fundamental question of whether the concepts of the astronomical unit and ephemeris time should be retained or replaced by the use of SI units of length and time (i.e. the metre and the atomic second). The Chairman considers that neither of the extreme viewpoints is likely to be generally acceptable and that we should adopt a system which allows either astronomical or SI units to be used. The relationships between the two sets of units must be clearly and unambiguously specified, even though the numerical values of some of the conversion factors will be subject to determination by observation. It is suggested that this can be achieved in the following manner, but it must be emphasised that the Group has not yet decided whether this represents the optimum system.

There are two main arguments that determine the general structure of the system. Firstly, that the practical objections to the use of ephemeris time as now defined are so great that it would be preferable to adopt a gravitational time scale that, for general astronomical purposes, is identical 